\title{
Experimental malnutrition: A systematic review
}

Marcus Vinicius Henriques Brito ${ }^{1}$, Mauro de Souza Pantoja ${ }^{2}$, Ana Paula Santos Oliveira Brito ${ }^{3}$, Caroline da Silva Alves Palheta ${ }^{3}$, Wescley Miguel Pereira da Silva ${ }^{4 *}$ and William Costa da Silva ${ }^{5}$

${ }^{1}$ Department of General Surgery, Universidade Estadual do Pará (UEPA), Belém-PA, Brazil

${ }^{2}$ Coordinator of the EMTN (Multidisciplinary Team of Nutritional Therapy, Universidade Estadual do Pará (UEPA), Belém-PA, Brazil

${ }^{3}$ Fellow Master degree, Postgraduate Program in Surgery and Experimental Research, UEPA, Belém-PA, Brazil

${ }^{4}$ Graduate student, School of Medicine, Universidade Federal do Pará (UFPA), Belém-PA, Brazil

${ }^{5}$ Graduate student, School of Medicine, Universidade Estadual do Para(UEPA), Belém-PA, Brazil

\begin{abstract}
The protein-energy malnutrition (PEM) is an important public health problem. This study aimed to perform a systematic review of articles published in English and Portuguese in the last decade, aimed at research on experimental malnutrition. It was selected studies published from January 2006 to August 2015 . The descriptors used were from "modelo de desnutrição" and "model of malnutrition”. The databases consulted were Scielo, PubMed, Lilacs and Cochrane Library. In 17 articles, positive and negative outcomes of malnutrition were searched in different databases. Among these, 8 articles researched the correlation of malnutrition with immune system or gastrointestinal system and 5 articles analyzed the hematopoietic system and the skeletal system. Only 1 paper analyzed the cardiovascular system, 1 analyzed the cutaneous system and 2 the malnutrition itself. Experimental malnutrition articles need to standardize models for malnutrition in more details throughout his writings. Furthermore, it was observed that the studies about malnutrition did not search the relation between surgical stress and malnutrition.
\end{abstract}

\section{Introduction}

The protein-energy malnutrition (PEM) is a major public health problem that affects millions of people worldwide and can be described as a form of malnutrition where there is inadequate calorie or protein intake. Extreme cases induces in the individual a series of biochemical and organic changes, causing changes in bodily function, and is associated with worsening of the diseases [1].

The PEM has been a statistically significant problem in surgical patients, affecting $22-58 \%$ of cases, and is related to higher hospital costs, longer hospitalization, predisposing to a variety of complications, higher incidence of infections and mortality [2]. Clinically, the PEM can be classified into marasmus (deficiency in calorie intake), kwashiorkor (protein malnutrition predominant) or a combination of both, marasmus-kwashiorkor [3].

In this context, laboratory animals have been used increasingly to assess the effects of malnutrition degrees variables in susceptibility to infections and also in the various parameters of the immune response, as well as in several pathologies related to malnutrition [1]. The big advantage of using animal models is to allow highly controlled evaluation of each nutritional parameter, considering that is not possible in the case of human populations.

In this scenario, the present study was to conduct a systematic review of articles published in English and Portuguese in the last decade, aimed at research on experimental malnutrition.

\section{Materials and method}

The included studies were about experimental malnutrition, published from January 2006 until August 2015. Keywords used were "modelo de desnutrição" and "model of malnutrition". Data bases consulted were Scielo, Pubmed, Lilacs and Cochrane Library. It was established the following criteria for inclusion: studies which used extrauterinos animals (post-natal) and articles which were published 10 years ago. As criteria for exclusion: articles with incomplete information and review articles (only original articles were included).

\section{Results}

According to elegebility criteria, 17 articles were identified during the study period and are presented in Table 1, and 9 of these ones were published since 2011, showing that the issue is still current. As the place of origin of the articles, 8 of them are from South America, 4 from Europe, 1 from North America and 2 in Asia.

In 17 articles, there was the analysis of different systems in search of positive and negative impacts of malnutrition. It was found 8 articles researching the relationship between malnutrition with the immune system and/or gastrointestinal system, while 5 articles analyzed the hematopoietic system and the skeletal system. Only one paper analyzed the cardiovascular system, one analyzed the cutaneous and 2 studies, just the malnutrition process.

About the experimental animals used, 16 used mice and the pig was used in only one study. The time for induction of the malnutrition was 21 days in 4 studies, while less than 21 days in 5 studies and two weeks or less in 6 studies.

To induction to malnutrition was used the low protein diet mainly, associating this with the low supply of calories in 4 studies. The study by Leite et al., we used 2 methods to get malnutrition, the

Correspondence to: Wescley Miguel Pereira da Silva, Graduate student, School of Medicine, Universidade Federal do Pará (UFPA), Belém-PA, Brazil; E-mail: wesmiguel@hotmail.com

Keywords: protein malnutrition, protein-energy malnutrition, malnutrition

Received: April 10, 2016; Accepted: April 29, 2016; Published: May 03, 2016 
Table 1. Articles about experimental malnutrition published from January 2006 until August 2015.

\begin{tabular}{|c|c|c|c|c|c|c|c|c|c|c|}
\hline Year & Tittle & Country & Author(s) & Studied system & Animal & Model & $\begin{array}{l}\text { Induction time } \\
\text { to malnutrition }\end{array}$ & Effects & Sex & $\begin{array}{l}\text { Number } \\
\text { of } \\
\text { animals }\end{array}$ \\
\hline 2006 & $\begin{array}{l}\text { Preventive strategy } \\
\text { for Candida gut } \\
\text { translocation during } \\
\text { ischemia-reperfusion } \\
\text { injury supervening } \\
\text { on protein-calorie } \\
\text { malnutrition }\end{array}$ & China & Marotta et al. [15] & Gastrointestinal & $\begin{array}{l}\text { Rat Sprague- } \\
\text { Dawley }\end{array}$ & $\begin{array}{l}\text { Low protein diet } \\
(2,5 \% \text { casein })\end{array}$ & 7 days & $\begin{array}{l}\text { Significant increase in } \\
\text { permeability of the colon } \\
\text { malnourished rats. The groups } \\
\text { treated with Compound showed } \\
\text { partial improvement of this } \\
\text { parameter }\end{array}$ & Uninformed & 90 \\
\hline \multirow[t]{2}{*}{2007} & \multirow[b]{2}{*}{$\begin{array}{l}\text { Rapid restoration } \\
\text { of colonic goblet } \\
\text { cells induced by } \\
\text { a hydrolyzed diet } \\
\text { containing probiotics } \\
\text { in experimental } \\
\text { malnutrition }\end{array}$} & \multirow[t]{2}{*}{ Brazil } & Dock -Nascimento, & \multirow[t]{2}{*}{ Gastrointestinal } & \multirow[t]{2}{*}{ Rat Wistar } & \multirow{2}{*}{$\begin{array}{l}\text { aproteic } \\
\text { (Rhöster) }\end{array}$} & \multirow[t]{2}{*}{12 days } & \multirow{2}{*}{$\begin{array}{l}\text { Malnutrition decreased } \\
\text { the number of goblet cells } \\
\text { throughout the colon. }\end{array}$} & \multirow[t]{2}{*}{ Male } & \multirow[t]{2}{*}{26} \\
\hline & & & $\begin{array}{l}\text { Junqueira e Aguilar- } \\
\text { Nascimento [12] }\end{array}$ & & & & & & & \\
\hline 2007 & $\begin{array}{l}\text { Reduction of erythroid } \\
\text { progenitors in protein- } \\
\text { energy malnutrition }\end{array}$ & Brazil & Borelli et al. [19] & Hematopoietic & Rat swiss & $\begin{array}{l}\text { Low protein diet } \\
(20 \mathrm{~g} / \mathrm{kg} \text { - casein) }\end{array}$ & 14 days & $\begin{array}{l}\text { Anemia of protein-energy } \\
\text { malnutrition was the result of } \\
\text { ineffective erythropoiesis. }\end{array}$ & Male & 38 \\
\hline 2007 & \begin{tabular}{|l|} 
Contribution of \\
polyunsaturated fatty \\
acids to intestinal \\
repair in protein-energy \\
malnutrition
\end{tabular} & Spain & Nieto et al. [14] & Gastrointestinal & Rat & $\begin{array}{l}\text { Low protein diet } \\
\text { and hypocaloric } \\
\text { (rich in lactose) }\end{array}$ & 14 days & $\begin{array}{l}\text { Polyunsaturated fatty acids } \\
\text { in the diet can influence the } \\
\text { intestinal repair in chronic } \\
\text { diarrhea due to protein-energy } \\
\text { malnutrition. }\end{array}$ & Male & 80 \\
\hline 2007 & $\begin{array}{l}\text { Restoration by dietary } \\
\text { glutamine of reduced } \\
\text { tumor necrosis factor } \\
\text { production in a low- } \\
\text { protein-diet-fed rat } \\
\text { model }\end{array}$ & Japan & Komatsu et al. [10] & Immune & Rat Donryu & $\begin{array}{l}\text { Low protein diet } \\
\text { (3\% casein) }\end{array}$ & 21 days & $\begin{array}{l}\text { TNF production by reduction } \\
\text { malnourished rat macrophages. }\end{array}$ & Male & 24 \\
\hline 2008 & $\begin{array}{l}\text { Protein-energy } \\
\text { malnutrition modifies } \\
\text { the production of } \\
\text { interleukin-10 in } \\
\text { response to Lipopoly } \\
\text { saccharide (LPS) in a } \\
\text { murine model }\end{array}$ & Brazil & Fock et al. [6] & $\begin{array}{l}\text { Skeletal system e } \\
\text { hematopoietic }\end{array}$ & $\begin{array}{l}\text { Rat Swiss } \\
\text { Webster }\end{array}$ & $\begin{array}{l}\text { Low protein diet } \\
\text { ( } 4 \% \text { proteína })\end{array}$ & 14 days & $\begin{array}{l}\text { Increased circulating levels of } \\
\text { IL - } 10 \text { in response to LPS. }\end{array}$ & Male & 84 \\
\hline 2009 & \begin{tabular}{|l|} 
Protein-energy \\
malnutrition decreases \\
immune response to \\
Leishmania chagasi \\
vaccine in BALB/c \\
mice
\end{tabular} & Brazil & Malafaia et al.[8] & Immune & Rat Balb/c & $\begin{array}{l}\text { Low protein diet } \\
\text { and isocaloric } \\
(3 \% \text { casein })\end{array}$ & 6 weeks & $\begin{array}{l}\text { Malnutrition can alter the } \\
\text { response to L chagasi vaccine } \\
\text { in rats even following } \\
\text { nutritional supplementation. }\end{array}$ & $\begin{array}{l}\text { Male and } \\
\text { female }\end{array}$ & 40 \\
\hline 2010 & $\begin{array}{l}\text { PTH improves titanium } \\
\text { implant fixation more } \\
\text { than pamidronate } \\
\text { or renutrition in } \\
\text { osteopenic rats } \\
\text { chronically fed a low } \\
\text { protein diet }\end{array}$ & Switzerland & Dayer et al. [18] & Skeletal system & $\begin{array}{l}\text { Rat Sprague- } \\
\text { Dawley }\end{array}$ & $\begin{array}{l}\text { Low protein diet } \\
\text { and isocaloric } \\
(2,5 \% \text { casein })\end{array}$ & 6 weeks & $\begin{array}{l}\text { Reduction of malnourished } \\
\text { rats force and PTH } \\
\text { reversed the deleterious } \\
\text { effects of malnutrition in } \\
\text { mechanical fastening and } \\
\text { microarchitecture. }\end{array}$ & Female & 41 \\
\hline 2011 & $\begin{array}{l}\text { Animal model of } \\
\text { undernutrition for the } \\
\text { evaluation of drug } \\
\text { pharmaco kinetics }\end{array}$ & Spain & $\begin{array}{l}\text { Merino-Sanjuán et } \\
\text { al. [22] }\end{array}$ & $\begin{array}{l}\text { Malnutrition } \\
\text { only }\end{array}$ & Rat Wistar & $\begin{array}{l}\text { Low protein diet } \\
\text { and hypocaloric } \\
(5 \% \text { protein })\end{array}$ & 26 days & $\begin{array}{l}\text { The proposed mathematical } \\
\text { model allows the body weight } \\
\text { of animals to be predicted } \\
\text { at a given time taking into } \\
\text { account the diet followed in the } \\
\text { experimental period. }\end{array}$ & Male & 133 \\
\hline 2011 & $\begin{array}{l}\text { Modelos experimentais } \\
\text { de desnutrição e sua } \\
\text { influência no trofismo } \\
\text { cutâneo }\end{array}$ & Brazil & Leite et al. [3] & Cutaneous & Rat Wistar & $\begin{array}{l}\text { Marasmus (half } \\
\text { the standard diet) } \\
\text { and Gelatine }\end{array}$ & 60 and 30 days & $\begin{array}{l}\text { Dermis thinner, lighter weight } \\
\text { and less collagen. }\end{array}$ & Male & 120 \\
\hline 2011 & \begin{tabular}{|l|} 
Avaliação da \\
gasometria arterial \\
de ratos desnutridos \\
submetidos à anestesia \\
inalatória por éter \\
etílico em vaporizador \\
artesanal
\end{tabular} & Brazil & Pantoja et al. [20] & $\begin{array}{l}\text { Malnutrition } \\
\text { only }\end{array}$ & Rat Wistar & $\begin{array}{l}\text { Low protein diet } \\
\text { ("polvilho") }\end{array}$ & 21 days & $\begin{array}{l}\text { The process of malnutrition } \\
\text { was effective in reducing } \\
\text { weight, serum albumin and } \\
\text { bicarbonate. }\end{array}$ & Male & 20 \\
\hline 2012 & \begin{tabular}{|l|} 
Post-Weaning protein \\
malnutrition increases \\
blood pressure and \\
induces endothelial \\
dysfunctions in rats \\
\end{tabular} & Brazil & Belchior et al. [21] & Cardiovascular & Rat Wistar & $\begin{array}{l}\text { Low protein diet } \\
\text { and hypocaloric } \\
\text { ( } 9 \% \text { protein- } \\
\text { ration RBD) }\end{array}$ & 3 months & $\begin{array}{l}\text { Protein malnutrition after } \\
\text { weaning increases blood } \\
\text { pressure and induces vascular } \\
\text { dysfunction. }\end{array}$ & Male & 20 \\
\hline
\end{tabular}




\begin{tabular}{|c|c|c|c|c|c|c|c|c|c|c|}
\hline 2012 & $\begin{array}{l}\text { Modulation of the } \\
\text { nuclear factor- } \\
\text { kappa B (NF-kB) } \\
\text { signalling pathway by } \\
\text { glutamine in peritoneal } \\
\text { macrophages of a } \\
\text { murine model of } \\
\text { protein malnutrition }\end{array}$ & Brazil & Lima et al. [7] & Immune & Rat Balb/c & $\begin{array}{l}\text { Low protein diet } \\
\text { ( } \% \text { protein) }\end{array}$ & 21 days & $\begin{array}{l}\text { The malnourished animals } \\
\text { showed anemia, leukopenia, } \\
\text { lower concentration of } \\
\text { glutamine in the state of } \\
\text { malnutrition . The plasma } \\
\text { interferes with the activation } \\
\text { of macrophages and higher } \\
\text { concentrations of glutamine, in } \\
\text { vitro, can negatively affect the } \\
\text { NF-кB pathway. }\end{array}$ & Male & 20 \\
\hline 2013 & $\begin{array}{l}\text { An animal model of } \\
\text { Kashin-Beck disease } \\
\text { induced by a low- } \\
\text { nutrition diet and } \\
\text { exposure to T-2 toxin }\end{array}$ & China & Kang et al. [4] & Skeletal system & $\begin{array}{l}\text { Rat Sprague- } \\
\text { Dawley }\end{array}$ & $\begin{array}{l}\text { Low protein } \\
\text { diet, rich in } \\
\text { barley }(10,2 \% \\
\text { protein) }\end{array}$ & 4 weeks & $\begin{array}{l}\text { Radiographic and histological } \\
\text { abnormalities of the tibia. }\end{array}$ & $\begin{array}{l}\text { Male and } \\
\text { female }\end{array}$ & 120 \\
\hline \multirow[t]{2}{*}{2013} & \multirow[b]{2}{*}{$\begin{array}{l}\text { Acute effects } \\
\text { of rotavirus and } \\
\text { malnutrition on } \\
\text { intestinal barrier } \\
\text { function in neonatal } \\
\text { piglets }\end{array}$} & United & \multirow[t]{2}{*}{ Jacobi et al. [13] } & \multirow[t]{2}{*}{ Gastrointestinal } & \multirow[t]{2}{*}{ Pig } & \multirow{2}{*}{$\begin{array}{l}\text { Low protein } \\
\text { diet and } \\
\text { hypocaloric(half } \\
\text { the standard diet) }\end{array}$} & \multirow[t]{2}{*}{3 weeks } & \multirow{2}{*}{$\begin{array}{l}\text { Lower weight, diarrhea . In } \\
\text { infected villi and reduction of } \\
\text { lactase activity and increased } \\
\text { crypt depth. }\end{array}$} & \multirow{2}{*}{$\begin{array}{l}\text { Male and } \\
\text { female }\end{array}$} & \multirow[t]{2}{*}{24} \\
\hline & & States & & & & & & & & \\
\hline 2013 & $\begin{array}{l}\text { Effect of a probiotic } \\
\text { fermented milk on } \\
\text { the thymus in Balb/c } \\
\text { mice under non- } \\
\text { severe protein-energy } \\
\text { malnutrition }\end{array}$ & Argentina & Núñez et al. [17] & $\begin{array}{l}\text { Immune and } \\
\text { hematopoietic }\end{array}$ & Rat BALB/c & Low protein diet & 21 days & $\begin{array}{l}\text { Increase of immature } \\
\text { thymocytes in malnourished } \\
\text { rats and influence of probiotic } \\
\text { in the histological and } \\
\text { functional recovery of the } \\
\text { thymus. }\end{array}$ & $\begin{array}{l}\text { Male and } \\
\text { female }\end{array}$ & 35 \\
\hline 2013 & $\begin{array}{l}\text { Protein energy } \\
\text { malnutrition decreases } \\
\text { immunity and } \\
\text { increases susceptibility } \\
\text { to influenza infection } \\
\text { in mice }\end{array}$ & England & Taylor et al. [9] & Immune & Rat C57BL/6 & $\begin{array}{l}\text { Low protein diet } \\
\text { and isocaloric } \\
\text { ( } 2 \% \text { protein) }\end{array}$ & 3 weeks & $\begin{array}{l}\text { The malnourished mice } \\
\text { exhibited more severe disease } \\
\text { following infection with } \\
\text { influenza and lower specific } \\
\text { antibody response against the } \\
\text { virus. }\end{array}$ & Female & 72 \\
\hline
\end{tabular}

marasmus method and gelatine method, which is the normal protein diet administration associated with low quality protein. Pantoja et al. used "pouvilho" (a type of biscuit) as a method of induction.

Studies that measured and detected decrease in weight and body growth totaled 7. Serum albumin was kept unchanged only in 1 study. The study of Borelli et al. detected depression of the hematopoietic system, lowering of red blood cells and reticulocytes. Melchior et al. found endothelial dysfunction and high blood pressure in undernourished rats.

\section{Discussion}

On the analysis of studies of this review, it can be seen that the experimental malnutrition has become an important area for the better understanding of the pathophysiology of malnutrition. In this regard, several systems have been the subject of research around the world. In China, for example, a study investigated radiographic abnormalities [4]. However, it was the gastrointestinal and immune systems were revealed as the main targets of interest of the scientific community nowadays.

It is noteworthy that the most prevalent cause of immunodeficiency worldwide is severe malnutrition which affects up to $50 \%$ of the population in poor countries. The immunological changes resulting from malnutrition can affect both the innate immunity in respect of specific. It has been noted that the availability of components of the complement system and phagocytic function are compromised in malnutrition and this hampers the elimination of pathogens. Both the $\mathrm{C} 3$ level, which is the main component opsonic, and the ability of phagocytes to internalize and destroy pathogens, appear reduced in states of desnutrição [5]. Such statements have been exemplified in the studies that correlate immune system with malnutrition, where the main roads studied were the NF- $\mathrm{BB}$ and inhibiting macrophages by interleukin 10 [6-10].
The other most studied system was the gastrointestinal which is markedly affected by the effects of PEM. In general, PEM affects the gastrointestinal tract causing atrophy of the gastric and intestinal mucosa. In the stomach causes hyperplasia, ulcerated lesions, decreased hydrochloric acid, weakening of gastric barrier to bacteria. In the intestines, there is a reduction of crypts, villi and intestinal microvilli, size of enterocytes, decreased intestinal transit may generally to constipation, and due to attenuation of the immune system, it is usual to observe infections and diarreia [11-15]. Interestingly, other studies, malnutrition was not significantly contribute to the worsening of the intestinal barrier in rotavirus infection, or to decrease the potency of the vaccine against this pathogen $[13,16]$. The loss of thymocytes was identified in a study, this loss, as well as changes in the intestinal mucosa, they can be ameliorated by supplementation with probiotic fermented milk [17].

In addition to the immune, and gastrointestinal systems have also been studied bone and hematopoietic system, the main findings loss of bone cells leading to defects like deficient hematopoiesis, lacking blood cells. It has been evidenced histological and radiographic abnormalities in mouse models with Kashin-Beck disease induced malnutrition [4]. Treatment with parathyroid hormone is effective in reversing the deleterious effects of malnutrition long term [18]. In malnutrition, anemia is caused by deficient erythropoiesis as the serum iron and erythropoietin in malnutrition do not change [19].

Although all the selected works have placed on your method data related to diet adopted by the animals, few jobs that have adopted an explicit model of induction to malnutrition, which could easily be replicated by other authors. This was the case of the work of Pantoja et al. [20] and Leite et al. [3], both studies could be considered innovative. At first, it was used as food biscuit flour, "polvilho", (totally devoid of protein) in Wistar rats diet to check for changes that malnutrition can result in blood gas analysis. Leite et al. used two models to arrive 
malnutrition: marasmus model which was to halve the mice food portions and the gelatin model, which would correspond to normal protein diet associated with low protein quality [20,3]. In the skin, malnutrition causes loss of collagen with less dermal thickness and negatively influences the tropism cutaneous [3].

As the cardiovascular system, malnutrition induces endothelial dysfunction, an increase of superoxide and nitric oxide in addition to the increased blood pressure [21].

Merino-Sanjuan et al. [22] used the pharmacokinetic study for malnutrition in animal model. Conclusion was the body weight of animals can be predicted at a given time takin in account the diet followed in the experimental period.

It is believed that, as the main characteristics for a model malnutrition, are practicality, the induction time and the adequacy of the animal studied. The evaluated articles, however, can see a significant discrepancy between the induction time in the researched articles, which would justify closer future studies to validate the best induction time for certain species.

\section{Conclusion}

It was observed that it is necessary that the experimental malnutrition articles standardize models for induction malnutrition in more detail in the course of his writings, so that other authors may have access to these techniques and can replicate them. In addition, it was noted that the scientific arsenal is lacking in research correlating malnutrition to one of its main causes today: surgical stress.

\section{Acknowledgements}

Marcus Vinicius Henriques de Britto and Mauro de Souza Pantoja took part in conception, design and scientific content of the study, critical revision. Ana Paula Santos Oliveira Brito and Carolina Betânia de Jesus Mardock, Caroline da Silva Alves participated in statistical analysis and manuscript preparation. Wescley Miguel Pereira da Silva and William Costa da Silva are responsible for interpretation of data and manuscript preparation in English version.

\section{References}

1. Tuca A, Jimenez-Fonseca P, Gascón P (2013) Clinical evaluation and optimal management of cancer cachexia. Crit Rev Oncol Hematol 88: 625-636. [Crossref]

2. Gotink RA, Chu P, Busschbach JJ, Benson H, Fricchione GL, et al. (2015) Standardised mindfulness-based interventions in healthcare: an overview of systematic reviews and meta-analyses of RCTs. PLoS One 10: e0124344. [Crossref]

3. EORTC -QLQ-C30 scoring manual. The EORTC QLQ-C30 (2001) Third edition. pp 78.

4. Heeren A, Douilliez C, Peschard V, Debrauwere L, Philippot P (2011). Cross-cultural validity of the Five Facets Mindfulness Questionnaire: adaptation and validation in a French-speaking sample. Revue européenne de psychologie appliquée 61: 147-51.

5. Buccheri G, Ferrigno D, Tamburini M (1996) Karnofsky and ECOG performance status scoring in lung cancer: a prospective, longitudinal study of 536 patients from a single institution. Europ J Cancer 32A: 1135-41.

6. Cereda E, Limonta D, Pusani CD, Vanotti A (2006) Geriatric nutritional risk index: a possible indicator of short-time mortality in acutely hospitalized older people. $J \mathrm{Am}$ Geriatr Soc 54: 1011-12.

7. Zhang MF, Wen YS, Liu WY, Peng LF, Wu XD, et al. (2015) Effectiveness of Mindfulness-based Therapy for Reducing Anxiety and Depression in Patients With Cancer: A Meta-analysis. Medicine (Baltimore) 94: e0897-0890. [Crossref]

8. Rouleau CR, Garland SN, Carlson LE (2015) The impact of mindfulness-based interventions on symptom burden, positive psychological outcomes and biomarkers in cancer patients. Cancer Manag Res 7: 121-31.

Copyright: (C2016 de Britto MVH. This is an open-access article distributed under the terms of the Creative Commons Attribution License, which permits unrestricted use, distribution, and reproduction in any medium, provided the original author and source are credited. 